\title{
Factors Related to Stunting Incidence in Children Under- Five Years in Argodadi, Sedayu, Bantul
}

\author{
Yanasta Yudo Pratama ${ }^{1}$, Tri Ani Marwati ${ }^{1}$, Muhammad Syamsu Hidayat $^{1}$ \\ ${ }^{1}$ Master's Program in Public Health, Universitas Ahmad Dahlan, Yogyakarta, Indonesia \\ *Correspondence: yanasta2007053008@webmail.uad.ac.id Phone: +6282224008009
}

Received 27 February 2021; Accepted 05 Mei 2021; Published 14 August 2021

\section{ABSTRACT}

Background: Stunting is a chronic nutritional problem due to insufficient food intake with the standard nutritional needs - starting from pregnancy to 2 years of age. Stunting could be raising a lousy impact on children's health, inhibited brain development, motor development, and physical growth obstruction. Stunting is also harmful to national development because stunted children have low productivity and intelligence. This study aimed to determine the relationship between mother body height and the incidence of stunting in children aged 0-59 months in Argodadi, Sedayu, Bantul.

Methods: This research was an observational analytic with a case-control design. This study population was all mothers who have toddlers aged 0-59 months. The population was 690 respondents. We recruited 154 samples using random sampling - consisting of 77 cases and 77 controls. Microtoise, infatometer, questionnaire, and WHO Anthro were used to collect the data. Data were analyzed using descriptive and chi-square tests.

Results: The chi-square test shows that mother body height was associated with the incidence of stunting p-value 0.005 ( $p<0.05$ ); OR: $3.2 \mathrm{Cl}(1.37-7.52)$.

Conclusions: Mother body height is a risk factor for stunting in children aged 0-59 months.

Keywords: Stunting; Toddler; Mother Characteristic

\section{INTRODUCTION}

Stunting is a chronic nutritional problem due to food intake that does not follow standard nutritional needs, starting from pregnancy to the age of 2 years (1). In Indonesia, the prevalence of stunting is around $30.8 \%$, with $6.7 \%$ very short and $16.9 \%$ short (2). The World Bank Group (2018) stated that $37 \%$ of children under five in Indonesia were stunted (3). While in Daerah Istimewa Yogyakarta (DIY) in 2019 the prevalence of stunting is $19.8 \%$. The Bantul District in 2019 has $22.89 \%$ of stunting prevalence, making Bantul one of the 160 priority cities for tackling stunting in Indonesia (4).

The mother's health condition and nutritional status during pregnancy significantly affect the growth and development of the fetus. Mothers who experience anemia during pregnancy will give birth to Low Birth Weight (LBW) babies closely related to stunting. The high incidence of stunting influences several factors such as parity, birth spacing, maternal height, dietary care, 
and maternal age (5). Stunting can be severe for children's health, both in the short and long term-short-term adverse effects such as inhibited brain development, motor development, physical growth, and impaired metabolism. In a long time, stunting influences decreased learning achievement, cognitive decline, reduced productivity in adulthood and is very vulnerable to infection $(6,7)$.

Maternal height describes the previous nutritional and socioeconomic status of the mother. ; short posture could be caused by heredity due to pathological conditions due to hormone deficiency so that it has the opportunity to reduce the tendency of short genes. Short posture could also be due to maternal health factors due to nutritional deficiencies or disease. Mother's height is a body size measured using a microtoise from the toe to the head. People are categorized as short if they $<150 \mathrm{~cm}$ and normal if they $>150$ (8).

According to previous research, children born from too short mothers are at three times greater risk of stunting (9). Since childhood, women who have experienced stunting will experience growth problems, including reproductive disorders and complications during pregnancy. Mothers who are stunted have a more significant potential to have stunted children. It is called the intergenerational nutrition cycle (10). Based on the background in mind, this research aimed to determine the association between mother body height and the incidence of stunting in children aged 0-59 months. This research will provide potential risk factors associated with stunting and then enhance the policymaker's intervention to prevent stunting incidence in society.

\section{METHODS}

This research was conducted at the Posyandu for the Argodadi Sedayu Village area, Bantul, in February-March 2020. We employed analytic observational with a case-control study design. The study's population was all toddlers aged 0-59 months in Argodadi Sedayu Bantul, as many as 690 . According to our calculation, the minimum sample size was 63 ; then, we recruited 77 samples for each arm selected using simple random sampling to anticipated sample dropout.

The inclusion criteria for the sample was a mother with children aged 0-59 months that participate in the Posyandu, and they were able to participate in this study. The exclusion criteria were mothers and toddlers who had moved from the village of Argodadi and children under five with incomplete immunization history. The research instruments were a questionnaire and Microtoise. Stunting was measured with microtoise and entered into the WHO anthro application. The Chi-Square test was used to analyze the result. This research has been approved by the Ethics Committee Institute of Alma Ata University Yogyakarta with the number KE/AA/III/10121/EC/2020. 


\section{RESULTS}

A total of 154 respondents who was the mother of children under five have participated in this study. All of them were female. Table 1 shows the association between variables and stunting. One variable was statistically significantly associated with stunting at $p \leq 0.05$ level: mother height. The test results using Fisher's exact or Chi-square test showed that the value of the Odds Ratio (OR) for the mother height with the incidence of stunting was 3.218. It means that children who had short mothers had higher odds (3.218 times) of stunting than tall mothers.

Table 1. Characteristics distribution of parent and toddler respondents

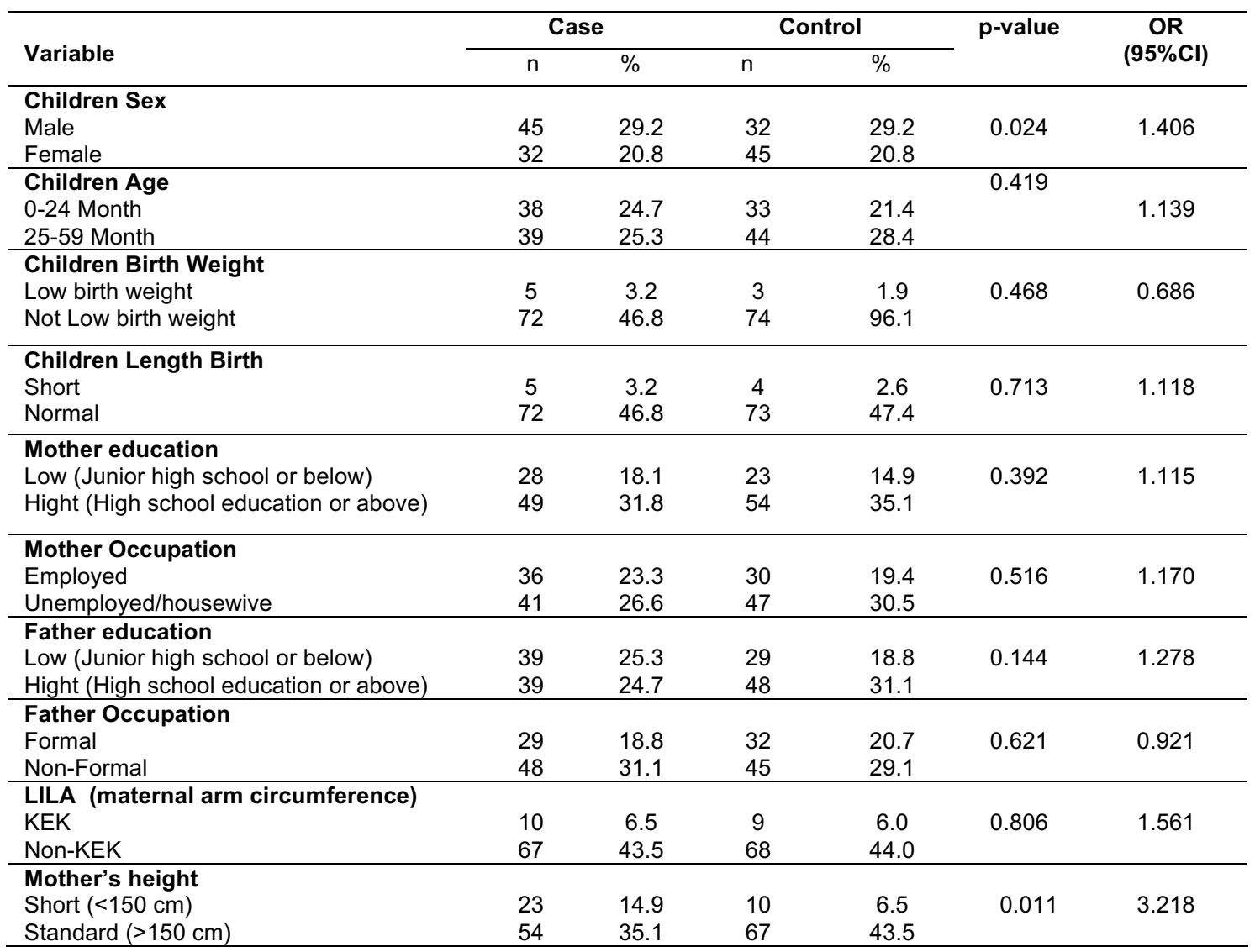

\section{DISCUSSIONS}

Short posture can indicate genetic disorders because the exact height is often unknown, increasing as a woman ages. According to Liselle, women with a height of less than $150 \mathrm{~cm}$ can be suspected of pelvic narrowing, which will impact fetal growth $(11,12)$. The factors that affect growth and development are divided into internal factors and external factors. Internal factors include genetic factors and hormonal factors. Both parents of children inherit the ability to be high. So tall children usually come from tall parents as well. Hormonal factors influence the development of bone cells. One of them is thyroid hormone which will affect the growth and maturation of bone cells themselves. While other hormones, namely sex hormones and hormones in the suprarenal glands, can also affect the maturation of bone cells, especially during puberty. External factors include the prenatal environment, such as lack of food intake during pregnancy, viral infections, and other diseases that can cause mental deterioration, body notes, and heart defects. The post-birth environment includes a lack of body-building 
foods, especially protein, which can interfere with growth. In addition, socioeconomic conditions play an essential role in people's development. Other factors that also affect growth are improved sanitation, education, and psychological factors (13).

This study indicates that males and females have the same risk for getting stunting. According to Larasati, research in 2018 revealed that the male sex is more susceptible to stunting in early life because the male body is more extensive and requires more nutritional intake if, at this time, it is not sufficient. Nutrition will result in the incidence of stunting. But in the second year of life, women are more at risk of experiencing stunting because it is related to parenting and nutrition in good conditions and environments; male growth is better than women (14).

Based on the characteristics of the parents, it shows that mothers with low education are more in the stunting group, namely as much as $18.1 \%$. While in the father's education, the percentage of stunting is higher in the group of fathers with low education, namely $25.3 \%$. This is in line with previous research that shows that maternal education is related to stunting and influences the incidence of stunting. Mothers with tertiary education have broader knowledge about child care practices and can maintain and care for their environment to keep them clean. Low maternal education can lead to stunting due to the lack of information obtained (15).

Parents' job characteristics show that respondents with mothers who do not work / IRT are more in the control group, namely, as many as 47 people $(30.5 \%)$ than the case group $(23.3 \%)$. The mother who does not work / IRT has a lot of time to take care of her child so that the pattern of care, hygiene, diet is well maintained, which affects the improvement of the nutritional status of children under five (16).

Respondents of their father's occupation mostly work non-formal $31.1 \%$ compared to the control group (29.1\%). According to Nadhiyah's research in 2014, parents' work affects the incidence of stunting because parental work affects income, affecting behavior, habits, and living norms in the family that are getting better. And this will encourage the improvement of the nutritional status of children under five (16). The maternal arm circumference (LILA) showed an equal proportion between the case group, namely ten people $(6.5 \%)$, and the control group as many as nine people (6.5\%). According to Warsini's research, it was revealed that the history of KEK during pregnancy was not related to the incidence of stunting. It was associated with the awareness of pregnant women to have their pregnancy checked, as for the PMT supplementary feeding program for pregnant women who suffer from chronic energy deficiency. Accordingly, the baby in the womb can continue to grow correctly (17).

Based on the child's birth weight, the percentage of LBW in the case group was $(3.2 \%)$, compared to the control group (1.9\%). Previous research reported that low birth weight affects the incidence of stunting with a $p$-value of 0.00 . Birth weight is an indicator of a child's survival, growth, and long-term health. Bodyweight is an indicator of the health of newborns, babies with low body weight will be vulnerable to adverse environmental influences in the future. So that growth and development will be slower, marked by suboptimal weight gain and height (18).

\section{Relationship between maternal height and the incidence of stunting}

The pelvic skeleton in a woman is related to reproductive functions. The size of a woman's pelvis is influenced by nutrition, environment, or other factors that cause the pelvis to be smaller than normal standards. At the same time, the shape of the female pelvis has a wider 
lower part for pregnancy purposes. Regardless of the vaginal birth of a normal-weight fetus, the pelvis with normal size will not experience difficulties during delivery. It potentially is difficult in vaginal delivery (19).

The results of this study indicate that maternal height is associated with the incidence of stunting. Mothers with short stature tend to have stunted children and vice versa. Mothers with standard height, the child will grow normally. The results of this study were in line with a previous study that said parents' height had a relationship with the incidence of stunting. Also supported by Wahdah, he stated that the mother's height was a risk factor for stunting (10). Genetic, environmental, and nutritional factors influence human growth. One form of gene expression is the mother's height.

Parents who have short posture due to environmental and nutritional conditions can still grow into normal height as long as the child is not exposed to other risk factors. However, if the mother is short due to genetic conditions, the child will likely inherit the gene, growing up to be stunted (20). In this condition, the children need nutritional attention during the life span of 1000 days starting from pregnancy or the equivalent of a 2-year-old toddler. $(19,20)$. Genetic characters that carry short also affect the performance of hormones that play a role in growth. The presence of growth hormone affects cortical bone build-up and may stimulate growth and height gain. This must be balanced with adequate nutritional intake to support growth so that the next generation will not be affected by growth failure or stunting (19).

\section{CONCLUSIONS}

Mother's height is significant as a risk factor for children grows stunted. Woman with short posture $[<150 \mathrm{~cm}]$, they have three times greater odds to have stunting children than mothers with tall posture [>150 cm]. To health workers, especially health workers in the village of Argodadi Sedayu, Bantul, it is suggested that they would monitor a woman's nutritional status during pregnancy. This can be done by conducting home visits to pregnant women and providing counseling to maintain the fetus's health.

\section{Authors' Contribution}

YYP, FB contributed to the research design and developed the first draft of the manuscript. YYP \& FB contributed to the data collection and statistical analysis. MSH and TAM contributed to evaluating this manuscript for publication.

\section{Acknowledgement}

We thank Futihatul Baidho who assisted the data collection for this research.

\section{Conflict of interest}

There are no conflicts of interest.

\section{References}

1. WHO. Stunting in a nutshell [Internet]. Web. 2015 [cited 2021 Aug 13]. Available from: https://www.who.int/news/item/19-11-2015-stunting-in-a-nutshell

2. Kementerian Desa Pembangunan Daerah Tertinggal dan Transmigrasi. Buku Saku Desa dalam Penanganan Stunting. Sandjojo EP, editor. Buku Saku Desa Dalam Penanganan Stunting. Jakarta: Kementerian Desa, Pembangunan Daerah Tertinggal, dan 
Transmigrasi; 2017. 42 p. Available from: https://stunting.go.id/kemendesa-buku-sakustunting-desa-2017/

3. The World Bank Group. Indonesia Accelerates Fight Against Childhood Stunting [Internet]. World Bank Group. 2018 [cited 2021 Aug 14]. Available from: https://www.worldbank.org/en/news/feature/2018/06/26/indonesia-fights-stuntingcommitment-convergence-and-communities

4. Luthfansa Z. Overview of Birth Body Length and Exclusive Breastfeeding and Breastfeeding in Stunting Children Age 6-59 Months in Patalan Village. J Healthc Technol Med [Internet]. 2020;5(2):2615-109.

5. Aridiyah FO, Rohmawati N, Ririanty M. The factors affecting stunting on toddlers in rural and urban areas). Pustaka Kesehat. 2015;3(1). [in Bahasa]

6. Dasman H. Four impacts of stunting for children and Indonesian. The Conversation [Internet]. 2019 Jan; Available from: http://repo.unand.ac.id/21312/1/Empat dampak stunting bagi anak dan negara Indonesia.pdf [in Bahasa]

7. Leksananingsih $\mathrm{H}$. The Relationship Between Stunting and Intelligence of 36-59 Months Old Children in Sedayu District, Bantul Regency, Yogyakarta. Universitas Alma Ata Yogyakarta; 2017. [in Bahasa]

8. Addo OY, Stein AD, Fall CH, Gigante DP, Guntupalli AM, Horta BL, et al. Maternal height and child growth patterns. J Pediatr. 2013;163(2):1-14.

9. Amin N A JM. Sociodemographic Factors and Height of Parents and Their Relationship with Stunting Incidence in Toddlers Age 6-23 Months. J Gizi dan Diet etik Indones. 2016;2(3):170-7. [in Bahasa]

10. Wahdah S, M J. Risk Factors for Stunting in Children aged 6-36 Months in Rural Areas of Silat Hulu Subdistrict, West Borneo. J Gizi dan Diet etik Indones. 2015;3(2):119-30. [in Bahasa]

11. Liselele HB, Boulvan M, Tshibangu KC, S M. Maternal height and external pelvimetry to predict cephalopelvic disproportion in nulliparous African women: A Cohort study. BJOG Int J Obstet Gynecol. 2005;107:947-52.

12. Wheeler L. Prenatal and Postpartum Care. Jakarta: Penerbit Buku Kedokteran EGC; 2003. 182 p. [in Bahasa]

13. Deswaty F. Factors Affecting Human Growth and Development. Bandung: Penerbit Yudhistira; 2007. 36-37 p. [in Bahasa]

14. Larasati NN. Factors Associated with Stunting Incidence in Toddlers Age 25-59 months at Posyandu in Wonosari II Health Center in 2017. Politeknik Kesehatan Yogyakarta; 2018. [in Bahasa]

15. Uliyanti, Tamtomo D. AS. Factors Associated with Stunting Incidence in Toddlers Age 2459 Months. J Vokasi Kesehat. 2017;3(2):1-11. [in Bahasa]

16. Nadiyah, Briawan D, Mastianto D. Risk factors for stunting in children aged $0-23$ months in the Provinces of Bali, West Java, and East Nusa Tenggara. J Gizi dan Pangan. 2014;9(2):125-32. [in Bahasa]

17. Kristiana Tri Warsini, Hadi H, Nurdiati DS. History of KEK and anemia in pregnant women is not related to the incidence of stunting in children aged 6-23 months in Sedayu subdistrict, Bantul, Yogyakarta. J Gizi dan Dietetik Indones. 2016;4(1):29-40. [in Bahasa]

18. Mustika $\mathrm{H}$. Dominant factors causing stunting incidents in children age 24-35 months in West Nusa Tenggara Province. J Sangkareang Mataram. 2016;2(1):51-8. [in Bahasa]

19. Wiknjosastro $H$. Midwifery. 4th ed. Jakarta: Yayasan Bina Pustaka Sarwono Prawirohardjo; 2009. 1-2 p. [in Bahasa]

20. Utami RA. The relationship between nutritional provision and stunting incidence in toddlers in Karang Anyar Village. J Kesehat Holist. 2017;1(2):22-31. [in Bahasa] 